\title{
Analysis of Production Factors for The Smallholder Rubber Sector in Malaysia
}

Journal of

Entrepreneurship and Business E-ISSN: $2289-8298$

Vol. 9, Issue 1, pp. 83-99. June. 2021

Faculty of Entrepreneurship and Business, Universiti Malaysia Kelantan

\section{Norlee Ramli}

Malaysian Rubber Board,

Email: norlee@lgm.gov.my

\section{Oswatun Samat}

Faculty of Economics and Management,

Universiti Kebangsaan Malaysia

Email: oswatun_samat@siswa.ukm.edu.my

Mohd Khairi Ismail (Corresponding Author)

Faculty of Business and Management,

Universiti Teknologi MARA, Malaysia

Email: khairiismail@uitm.edu.my

\section{(cc) $\mathrm{Br}$}

This work is licensed under a Creative Commons Attribution 3.0 Unported

\section{Nor Shuhada Ahmad Shaupi}

Faculty of Entrepreneurship and Business

Universiti Malaysia Kelantan

Email: shuhadashaupi@gmail.com

\begin{abstract}
The production of natural rubber in Malaysia is primarily dominated by smallholders representing almost $95 \%$ of the total rubber plantation, while commercial estates constitute the remainder. The natural rubber industry is an integral part of the Malaysian economy, with $2.6 \%$ of with the total contribution of exports valued at more than RM20 billion annually. Therefore, the three key inputs that affect the productivity of smallholders in all states throughout Malaysia should be critically explored There is limited literature on the production of rubber by smallholders. The labour consumption, land area and adherence to agronomic practices are the main inputs and variables in this study. The Ordinary Least Square (OLS) was used to analyse the correlation of each input with rubber production by referring to the concept of the production function. The results discovered that $96 \%$ of rubber production yields are explained by independent variables consisting of labour, plantation area, weeding and cultivating activities. Furthermore, the total plantation area and adherence to agronomic practices positively affect total rubber production, while inefficient use of labour negatively affects total rubber production.
\end{abstract}

Keywords: Rubber smallholders, multiple regression analysis, production function, agronomic practice.

\section{Introduction}

Natural rubber is one of the major commodities that contribute to national income. Large-scale rubber plantations were established at the beginning of the 1870s and are currently dominated by smallholders throughout Malaysia. Malaysian Rubber Board Journal of Entrepreneurship and Business 
Reports stated that $94.6 \%$ of national rubber production is produced by smallholders contributing to $2.6 \%$ of total exports worth more than RM20 billion annually. More than 420,000 smallholders are registered with the Rubber Fund Board, with 265,000 smallholders in Peninsular Malaysia, while the smallholders from Sabah and Sarawak constitute the rest. The Malaysian Rubber Board (MRB) has identified smallholders as individual planters with connected or subdivided planting areas, with an area less than 40.47 hectares (100 acres), planted with a type of crop or the cultivation of such crop is permitted and under a lawful title. This study aimed to analyse the main inputs that affect rubber production in the smallholder sectors throughout Malaysia, namely labour consumption, land area and adherence to agronomic practices with the total rubber production.

The land title and ownership of rubber plantation areas are categorised into two types of planters: independent planters and planters supervised under government agency plans. Independent planters are generally self-managed due to operation and management efficiency.. While, the supervised planters are more organised and monitored under government agencies such as the Federal Land Development Authority (FELDA), Rubber Industry Smallholders Development Authority (RISDA), National Land Consolidation and Rehabilitation Authority (FELCRA), Federal and State Government Land Plan (Department of Statistics Malaysia, 2010). In addition, other government agencies such as FELDA, FELCRA, RISDA Mini Estate, TSK (Commercial Replanting), LIGS and state development corporations have the responsibility to support the supervised planters by providing assistance in the form of weed killers, fertilisers, harvesting tools, agricultural equipment, and others to ensure the long-term sustainability of this sector (Rahman, 2020).

The total rubber plantation area of smallholders is comparatively bigger than the estate sector. In 2014, there were 342,180 individual rubber plantations throughout Malaysia, equivalent to 946,553 hectares. Nevertheless, according to the annual rubber statistics report for 2010 by the Department of Statistics Malay sia, there were only 185 estates in Malaysia with 49,740 hectares. These two sectors have displayed a significant downward trend in the total number of rubber plantations throughout the country. Figure 1 shows the total area in hectares for young and mature rubber plantations in 13 Malaysian states.

Lembaga Getah Malaysia (LGM) has defined young rubber plantation as the early rubber plantation phase to the age ready for tapping. In contrast, a mature rubber plantation is when most rubber trees have been tapped until tapping work is carried out in the panel tap which is BI-1 panel (including the ceased tapping areas that have stopped in that panel). The overall total area for mature rubber plantations is 218,221 hectares and 120,286.37 hectares for young rubber plantations. According to Figure 1, Kelantan in Peninsular Malaysia has the largest rubber plantation area with 54,116 hectares, while Sabah in East Malaysia has 57,075 hectares. 


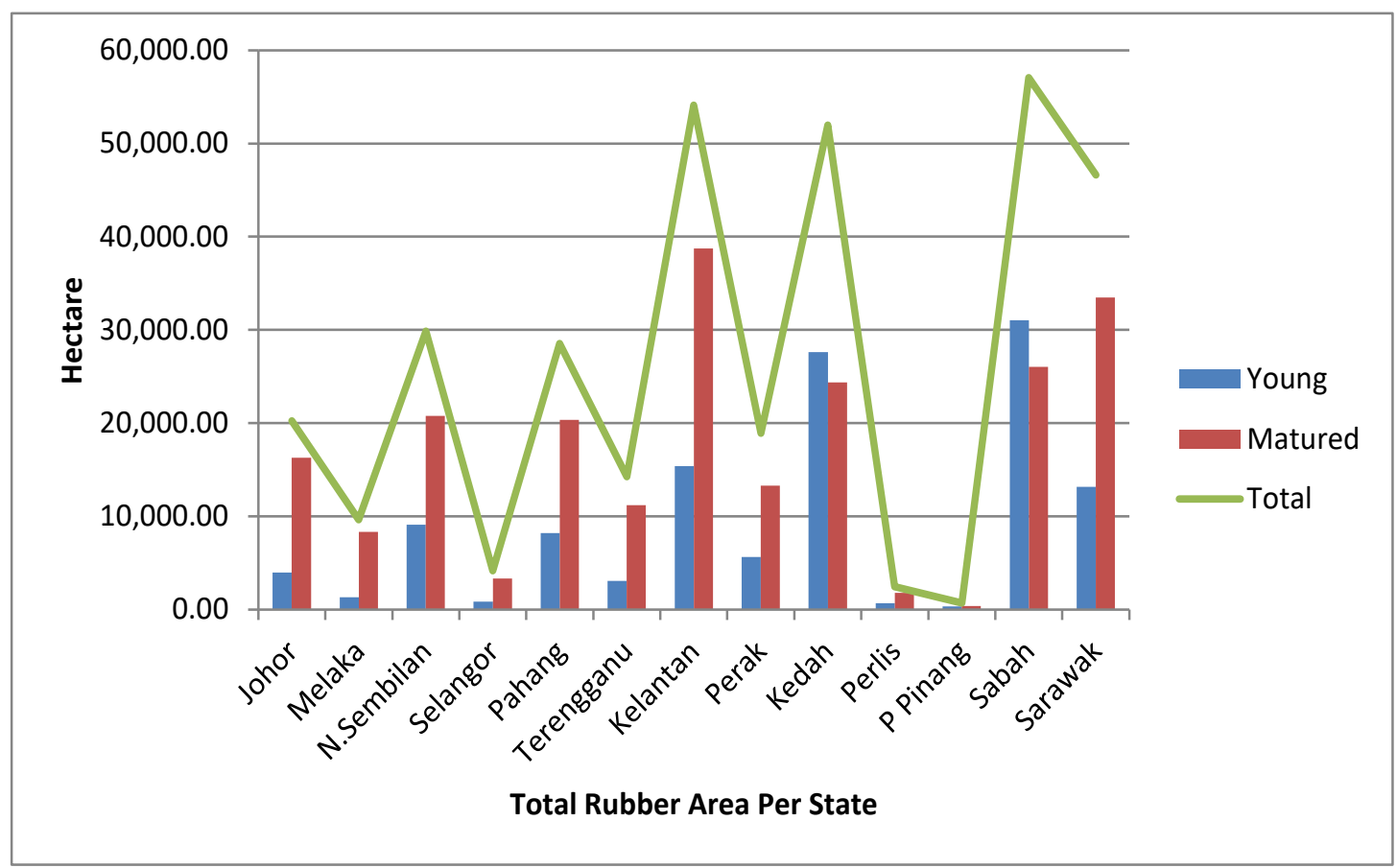

Figure 1. Area of young rubber plantations and matured rubber plantations in each state

The total rubber plantation area has decreased in the last years due to intense competition for land usage. A $26.04 \%$ reduction in rubber tree planting area was reported in 2010, approximately a total area of 0.97 million hectares compared to 1.31 million hectares in 2000 (Rafain, 2012). Table 1 below shows the changes in land use for agricultural purposes from 1987 to 2012 (Jamal, 2014).

Table 1: Planted area for different types of crops in 1987 and 2012

\begin{tabular}{lllll}
\hline & 1987 & & 2012 \\
\cline { 2 - 5 } Type of Crop & Planted Area & $\begin{array}{l}\text { Percentage of } \\
\text { agricultural } \\
\text { land used (\%) }\end{array}$ & Planted Area & $\begin{array}{l}\text { Percentage of } \\
\text { agricultural } \\
\text { land used (\%) }\end{array}$ \\
\hline Rubber & 1881.3 & 29.4 & 1041.5 & 13.2 \\
Palm Oil & 1640.2 & 25.7 & 5076.9 & 64.5 \\
Coconut & 320.6 & 5 & 112 & 1.4 \\
Cocoa & 370 & 5.8 & 21.7 & 0.28 \\
Paddy & 644.8 & 10.1 & 684.5 & 8.7 \\
\hline
\end{tabular}

Source: Department of Statistics Malaysia, 1985 - 2012 (Jamal Othman, 2014)

Each individual plantation area is less than two hectares each (MRB, 2019), making it impossible for planters to gain economies of scale and lead to inefficiency in rubber production. In addition, slow absorption of knowledge and application of the latest 
technology leads to inefficiency among smallholders. Other issues, such as ageing smallholders and labour shortage, have contributed to the low production of natural rubber as a tremendous decrease of individual tappers have been reported. The number of tappers in 1999 was 35,299 but has fallen by $70.4 \%$ leaving only 10,450 tappers in 2009. The significant shift of labour was due to expanding oil palm sector (Jamal, 2014).

\section{Literature Review}

\subsection{Production Trends in the Smallholder Rubber Sector}

The smallholder rubber sector is a major sector in the Malaysian rubber industry (Ali, Akber, Smith, \& Aziz, 2021). The sector produced $94.6 \%$ of the country's natural rubber production in 2011, equivalent to 0.99 million tonnes. The total area planted with rubber trees was $958,000.58$ hectares, covering $93.7 \%$ of the planted area nationwide (MRB Report, 2014). A comparison analysis of total production between these sectors and the estate sector is shown in Figure 2, where a significant difference from the production yield is visible.

The production output of the smallholder sector is inconsistent compared to estates due to the changes in rubber prices that influence the tapping activity among the farmers (Rafain, 2012; Abdulla \& Arshad, 2017). However, the incentives schemes, programmes and agricultural assistance from implementing agencies such as FELDA, FELCRA, RISDA Mini Estate, TSK (Commercial Replanting), LIGS and state development corporations had proven the importance of this sector to Malaysia's economic development (Bissonnette, 2017).

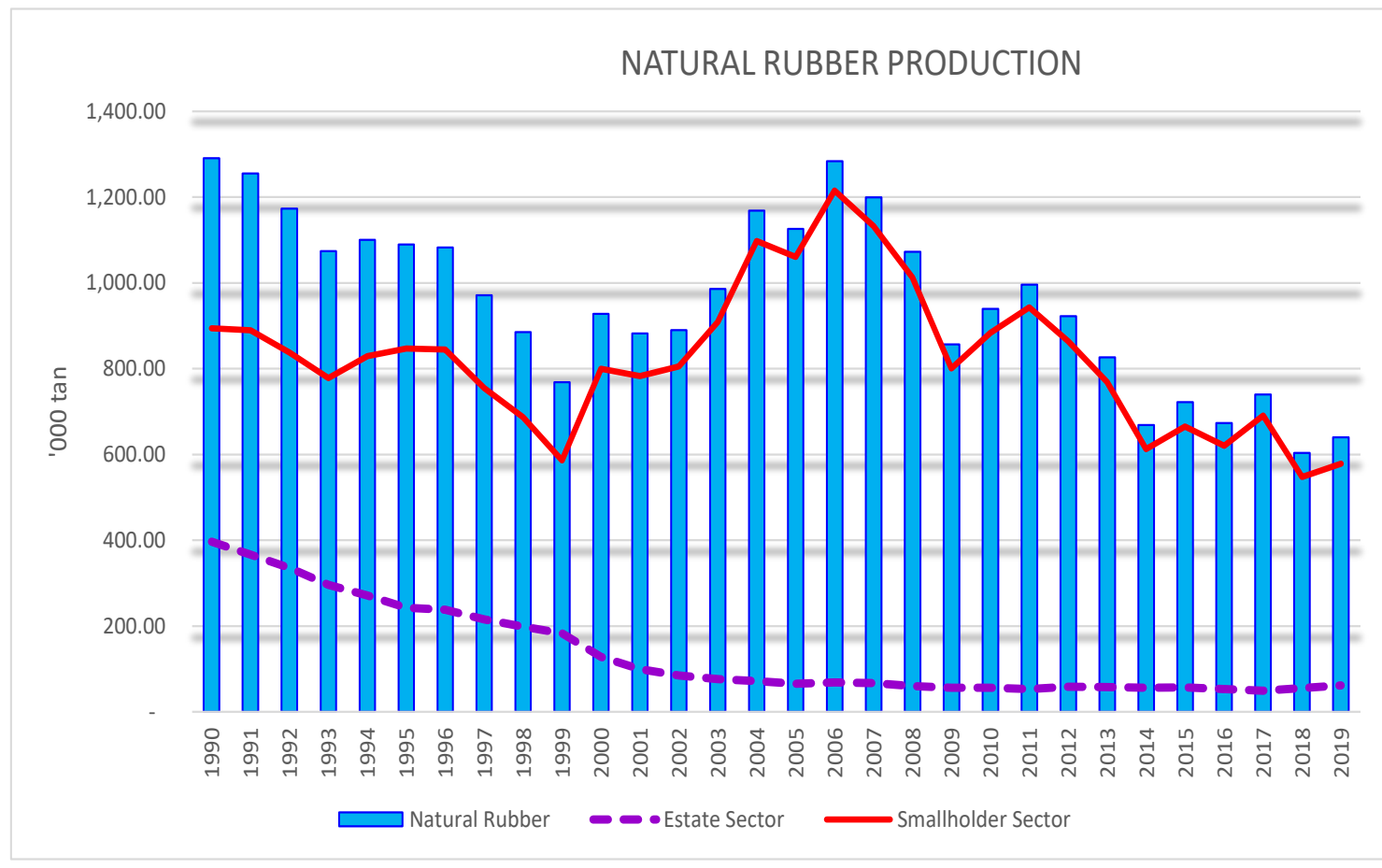




\section{Figure 2: The total production of natural rubber for the smallholder and estate sector}

The production curve showed a declining trend in rubber production, although this sector is the largest producer of natural rubber. Figure 3 illustrates the level of rubber production in this sector from 1990 to 2019.

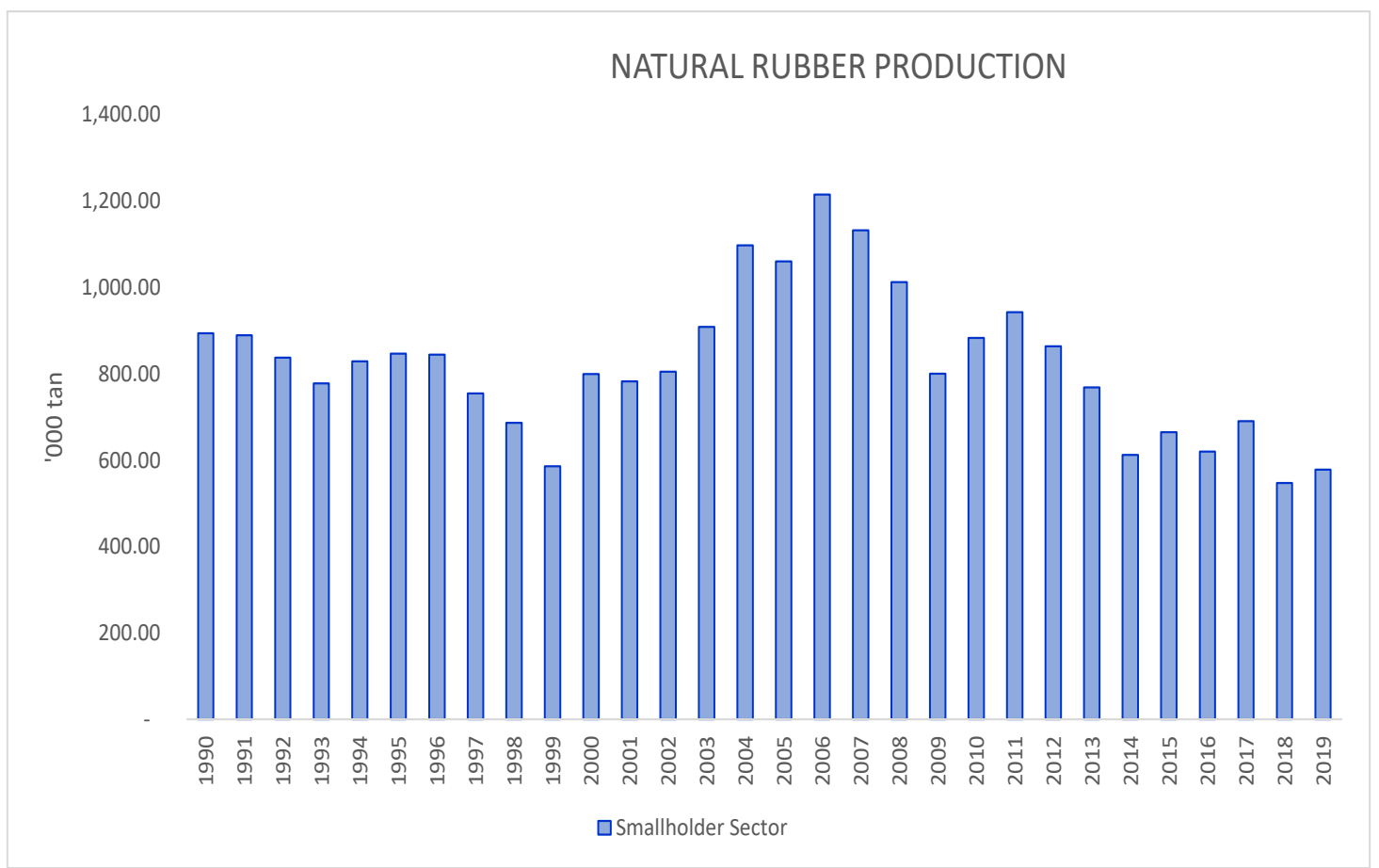

Figure 3: Rubber production by smallholder sector from 1990 to 2019

The primary reason for the declining rubber production is the reduction in the total rubber planted area where rubber plantations are converted into other crops. The quantity and quality of latex production depend on the suitability of the clones (Rabiah, Mohd. Fairuz Fazli \& Kamarozaman, 2015), soil type (Zahidin, Noordin \& Zulkefly, 2017) and terrain conditions (Ismail 1984). Government agencies such as the MRB and RISDA supply suitable clones to the farmers to optimise latex production. However, the productivity shown in this sector is far different from the actual rubber clones productivity potential recommended (Zulkefly et al., 2010).

\subsection{Factors Influencing the Untapped Matured Plantations}

The other factors, such as untapped matured rubber areas, had significantly affected the productivity of natural rubber in Malaysia. This study found that tapped matured rubber plantations comprise $62 \%$ of the total area, 36\% were young rubber tree plantations, while the remaining $2 \%$ consisted of untapped matured rubber plantations. The states of Kedah and Sabah have a larger young rubber tree plantations area than matured rubber area, comprising $53 \%$ and $54 \%$ of the total rubber plantation area, respectively. Figure 4 shows the total area of untapped matured rubber plantations in each state, covering an 
area of 6,958.30 hectares. The majority of these untapped plantations (4,094 farms), or $75 \%$, are found in Sarawak with approximately 5,410.89 hectares.

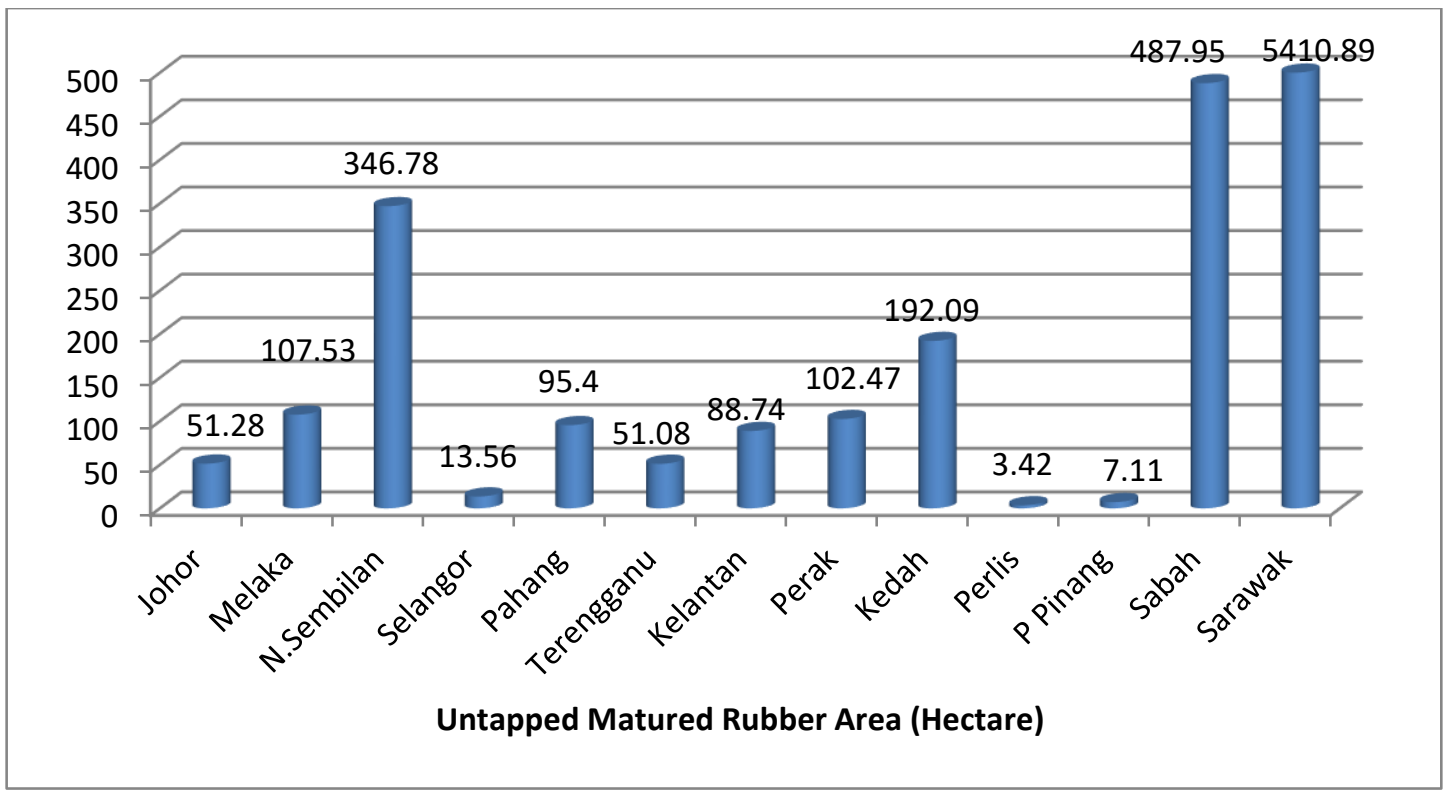

\section{Figure 4: Area of untapped matured rubber plantations in each state}

Several factors influence the untapped matured plantations and significantly affect the total rubber production, such as:

i. Insufficient workforce problem results in the farms to be left untapped.

ii. Transportation problem as some farms are located far from the homes of smallholders.

iii. Some smallholders have other major occupations.

iv. There are several other problems such as unproductive farms, old rubber trees, damaged rubber trees' barks that can no longer be tapped, dead rubber trees, and diseased rubber trees with no proper treatment administered.

v. Age factors, such as smallholders are getting old, depreciating health or illnesses, and not capable of cultivating or operating rubber plantations.

vi. Replanting process of rubber saplings to replace old rubber trees that no longer produce latex. Several rubber plantations are planning for replanting of rubber trees.

Labour efficiency in the smallholder sector also plays a vital role in ensuring high production of latex apart from the size of the plantation area. A total of 36,627 workers $\mathrm{h}$ hired to work in rubber plantations, with $89 \%$ local workers and $10 \%$ foreigners from Indonesia, Bangladesh, India, Cambodia, Thailand, Burma, Myanmar, Nepal and China. Figure 5 displays the number of labours (local and foreign labours) employed in the smallholder rubber sector for each state. 


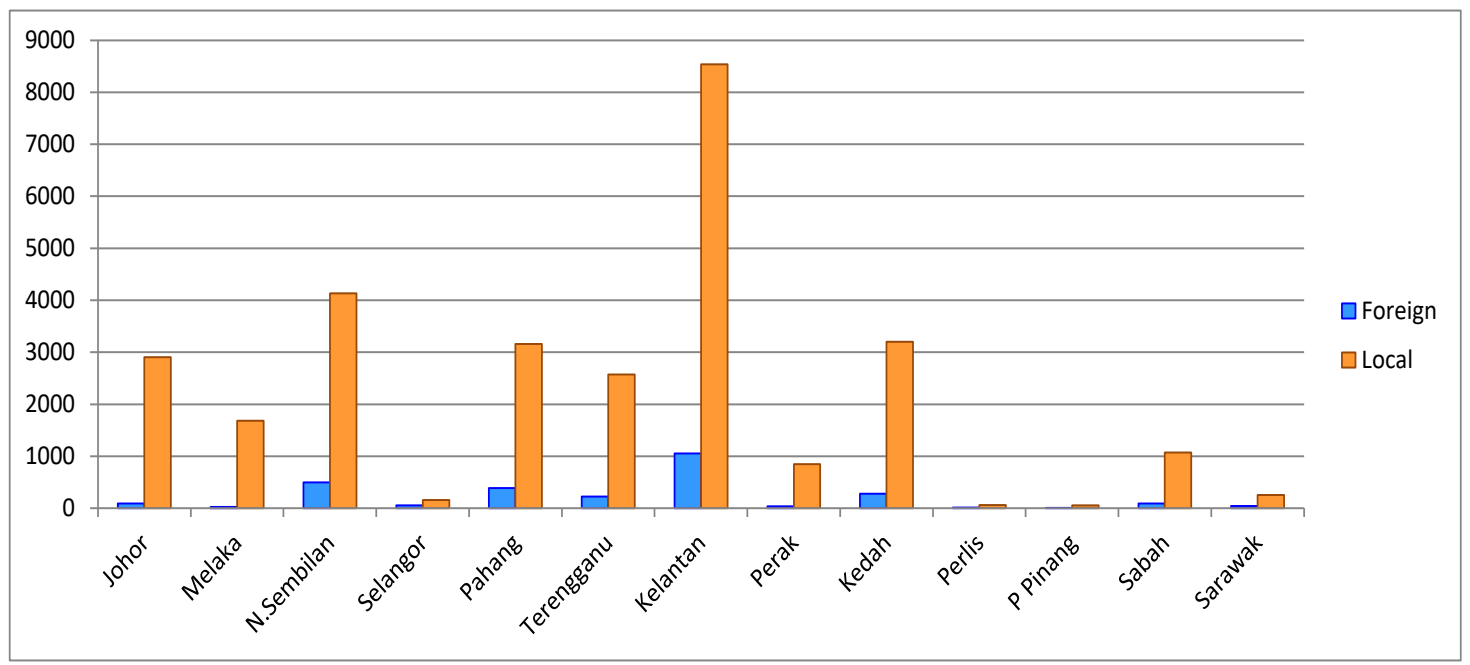

Figure 5: Total local and foreign labour in each state.

\subsection{Factors Influencing Rubber Production in Smallholder Sector}

Several other factors influence rubber production in the smallholder sector, especially agronomic practices such as fertilising and weeding. $41 \%$ of the farms had followed the fertilising recommendations, whereas $15 \%$ did not follow the recommendations. $42 \%$ of the farms have not been fertilised in the past year, mainly in Sabah and Sarawak, with 15,061 and 21,653 farms. Figure 6 shows the number of smallholders that followed the fertilisation recommendations, did not follow the recommendations and never fertilised the cultivated orchards.

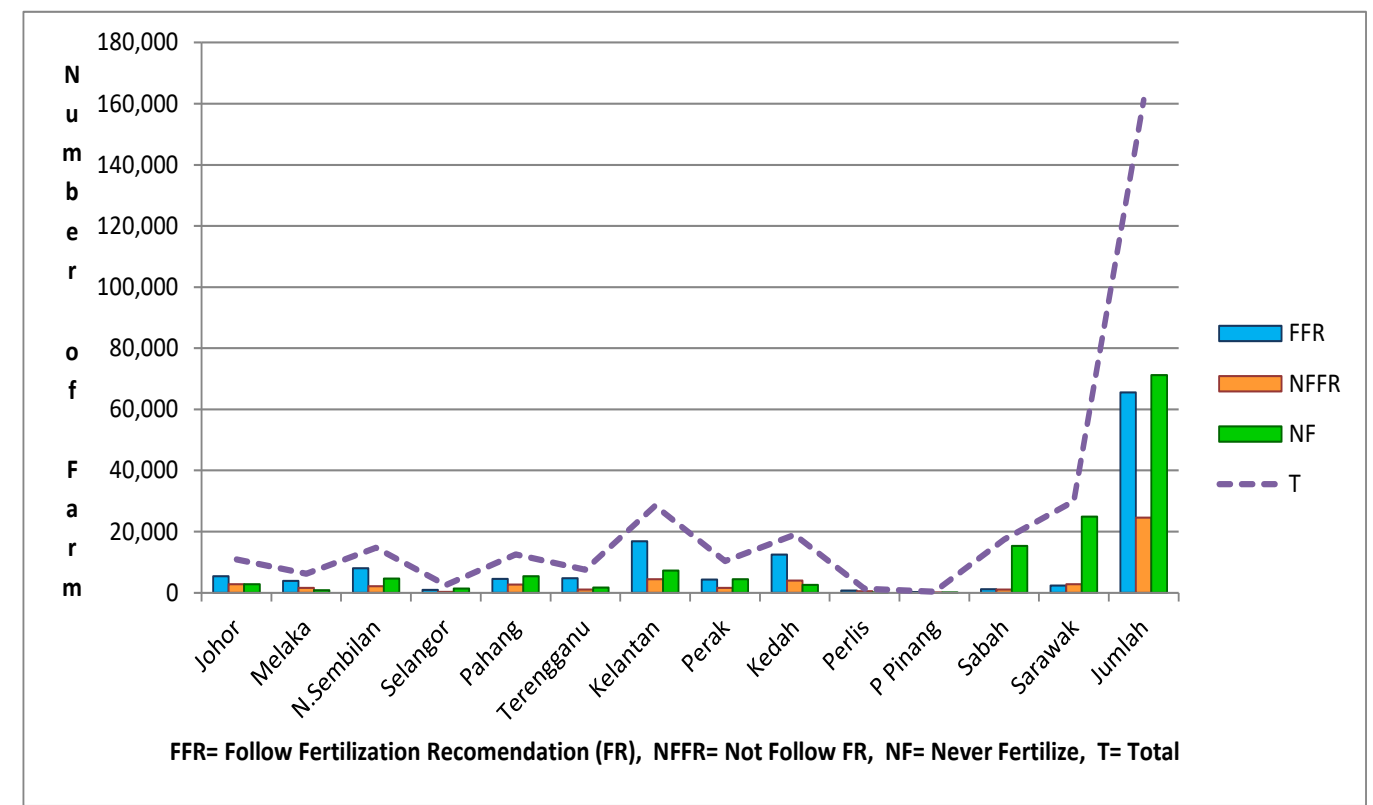

Figure 6: Fertilisation that follows the recommendations, does not follow the recommendations and never fertilises 
Similarly, weed control practices are divided into three methods. Figure 7 shows the number of farms that use chemical and manual (43\%), manual (37\%) and chemical $(18 \%)$ methods.

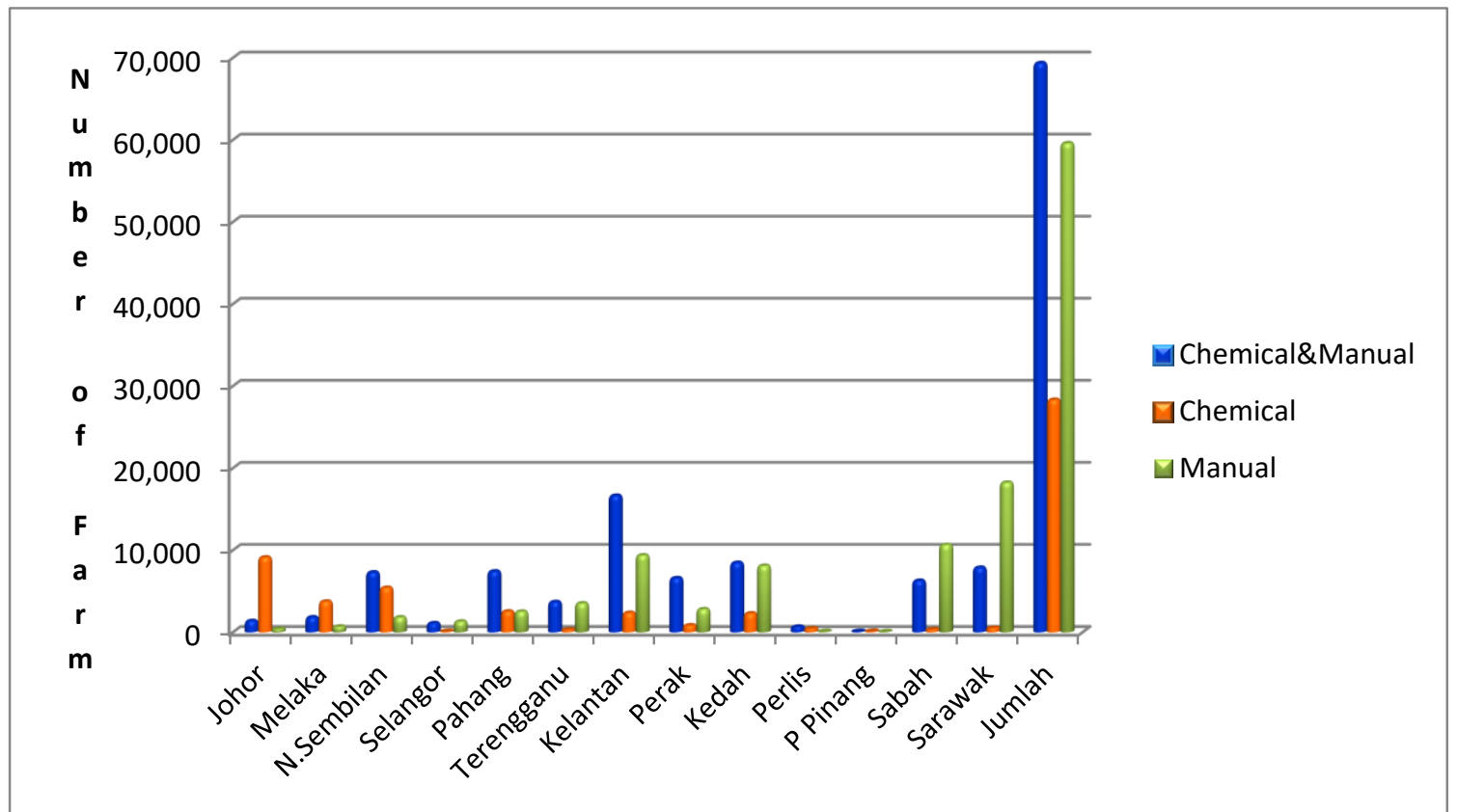

Figure 7: Weed control with chemical and manual methods, chemical method and manual method

Figure 8 shows the frequency of weeding activity carried out by the smallholders where the farms are weeded twice a year (46\%), thrice and more (30\%), and once annually $(21 \%)$.

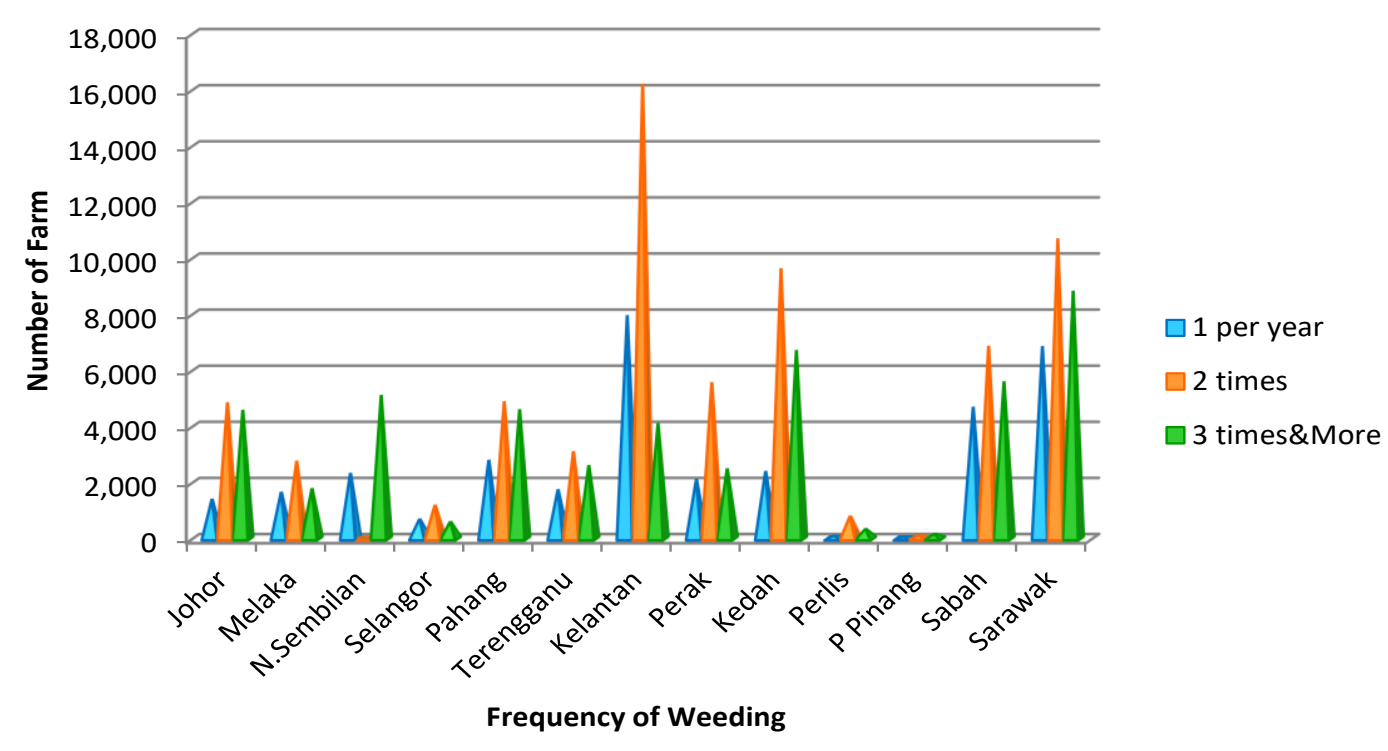

Figure 8: Frequency of weeding in a year for each state 


\section{Methodology of Study}

\subsection{Research Design}

This study aimed to analyse several main inputs that affect rubber production in the smallholder sector in Malaysian states. There are three main types of input: labour consumption, land area, and adherence to agronomic practices. A detailed study was carried out by examining the effect on total rubber production. This study used data from the Rubber Board Survey conducted in 2014 obtained from the MRB. Based on the production theory, the efficiency of using production inputs is analysed to compare the usage with production output. The OLS was utilised to test the relationship of each type of input to production output. In addition, the number of labours, land productivity and two agronomic practices of fertilising and weeding were tested to see the effect on rubber production throughout Malaysia. A quantitative research approach or crosssectional study design was adopted for this study.

\subsection{Empirical Model}

This study applied an empirical model based on the production theory that involves the application of inputs or production factors to output. Inputs are divided into three categories, namely capital, labour and raw materials. Capital inputs consist of land, buildings and equipment, whereas labour inputs are human resources-based services. Raw material inputs are the key materials used in the production process. The production process is formulated as a production function to describe the amount of input used to produce the maximum quantity of output. The basic production function for two basic inputs, namely labour and capital, are as follows:

$$
q=f(L, K)
$$

Where,

$\mathrm{q}=$ The number of output units produced

$\mathrm{L}=$ Units of labour input

$\mathrm{K}=$ Units of capital input

Economists subsequently expanded the use of each production function by adding inputs besides labour and capital. Hamermesh (1984) explained that using several specific production factors $(\mathrm{Xt})$ has generated a general production function for an industry as follows:

$$
\mathrm{Q}=\mathrm{f}\left(\mathrm{X}_{1}, \ldots, \mathrm{X}_{\mathrm{n}}\right), \operatorname{dengan} \mathrm{f}^{\prime}>0 \text { dan } \mathrm{f}^{\prime \prime}<0
$$

The production function can also be applied in the agricultural industry with a combination of capital inputs, labours, and other factors used, such as chemicals, fertilisers and others (Rosine, 1974), as expressed in the equation below:

$$
\mathrm{Q}=\mathrm{F}(\mathrm{A}, \mathrm{L}, \mathrm{K}, \mathrm{C})
$$


Where,

$$
\begin{aligned}
& \mathrm{Q}=\text { Production output } \\
& \mathrm{A}=\text { Land } \\
& \mathrm{L}=\text { Labour } \\
& \mathrm{K}=\text { Operating inputs (chemicals, fertiliser, oil) } \\
& \mathrm{C}=\text { Working capital (machinery, buildings) }
\end{aligned}
$$

This study applies the production function proposed by Rosine (1974) to consider the agronomic practices of weeding and fertilising as operational inputs in the production process. Ownership is not considered part of the production input as ownership in the smallholder sector is an individual right. Production inputs in the smallholder sector are similar, but input consumption's productivity level differentiates the production output. Productivity calculations for each input are evaluated based on the following measurements:

- Labour efficiency is assessed based on the amount of labour involved in the processing and selling rubber, either in the form of latex or pieces, compared to the production amount.

- Land use efficiency is assessed according to the planted area (hectares) and compared with total production.

- Technology is evaluated based on agronomic practices consisting of fertilising and weeding activities according to agency recommendations.

- Total production is the total collection and sale of rubber in the form of latex or pieces. Total production is assessed based on total weight [kilogrammes $(\mathrm{kg})]$. 


\subsubsection{Weeding Practices}

Weeds are unwanted plants that grow in farming areas, affect the growth of rubber trees and compete for light, water and nutrients in the rubber tree planting area. Farmers usually perform weeding to facilitate fertilising in controlling diseases attack on rubber trees as weeds also slow down the growth and prolong the rubber trees' maturity process. The frequency of weeding depends on the rubber trees' age. Farmers need to weed three to four times a year when the trees are zero to four years old and twice a year when the tree reaches the age of five to seven years.

Rubber plantations that reach the age of eight years and above only need to be weeded at least once annually (Ramli, 2012). A well-maintained plantation produces healthy and large rubber trees that guarantee latex production results. The relationship between weeding frequency and production rate is illustrated in Figure 2. The importance of weeding activity is proven to affect the production yield significantly.

\subsubsection{Fertilising Practices}

The growth of rubber trees can be categorised into two types, namely young and mature trees. These two categories depend on the type of fertiliser used and different fertilisation schedule. For example, young trees need to be fertilised 13 times until they reach maturity and can be tapped (Mohd. Fauzi, 2014). Matured trees need to be fertilised once annually throughout their life except for three years before the replanting process (Wan Noordin, 1991). Fertilisation is a critical element to ensure a good source of nutrients for the growth of rubber trees (Said, 2005). Proper fertilisation can increase latex production, stimulate the recovery of new bark after tapping, strengthen the defence system against leaf disease attacks, and accelerate the canopy formation between trees to produce shade that reduces weed growth. Lack of fertiliser stunts the trees' growth and affect the quantity of latex produced. However, excessive use of fertiliser encourages the growth of tree branches that can potentially break and damage the rubber tree.

Past studies have demonstrated the importance of fertilisation activities to the quality of trees and latex (Wan Noordin, 1991). Nevertheless, studies related to fertilisation activities in rubber production are limited, especially in the Malaysian smallholder sector. Past studies focused more on technical and scientific aspects, such as testing the effectiveness of fertilisation methods to suit soil types and clones (Zahidin, Noordin \& Zulkefly, 2017), rubber plantation density (Shima \& Kheong, 2008) and rubber tree growth (Salisu, David \& Ahmad, 2013).

\subsubsection{Agronomic Practices}

Good agronomic practices include the farm management system that follows agricultural recommendations by government agencies to reduce risks and increase agricultural yields. Good agronomic practices depend on each farmer to keep the plantation environment clean from pests that damage rubber trees. Smallholders who apply good agronomic practices achieve a productivity level of up to 2,000/hectare per year (Zainuddin, 2014). The weed control and fertilisation activities are ongoing practices that must be continuously practised throughout the planting and tapping during the same period to ensure optimal impact. For example, the farm environment should be 
cleaned. The area around the tree should be cleared of bushes and weeds before fertilisation activity to ensure that the fertiliser sown is absorbed only by the tree (MRB, 2010).

Based on the discussion on production theory, an ecometrics model for this study is formulated as below:

$$
Q=\alpha+\beta_{1} A+\beta_{2} L+\beta_{3} K+\beta_{4} C+\varepsilon
$$

Where,

$\beta=$ Coefficient

$\alpha=$ Intercept

$\varepsilon=$ Error term

$Q=$ Dependent variable

$A, L . K, C=$ Independent variable

\section{Findings and Discussion}

Table 2 shows the results obtained from the estimated model using multiple regression analysis. The dependent variable is the total rubber production. In contrast, the independent variable consist of fertilising practices, weeding practices, rubber plantation area and amount of labour involved in the smallholder rubber sector. Table 2 demonstrates that the model is good fit ( $\mathrm{p}$-value $=0.000$ ).

Table 2: Results of multiple regression analysis

\begin{tabular}{|c|c|c|c|c|c|c|}
\hline \multicolumn{2}{|c|}{ Model } & Sum of Squares & $d f$ & Mean Square & $\mathrm{F}$ & Sig. \\
\hline \multirow[t]{3}{*}{1} & Regression & 1603914139.049 & 4 & 400978534.762 & 26.891 & $.000^{\mathrm{b}}$ \\
\hline & Residual & 119291489.178 & 8 & 14911436.147 & & \\
\hline & Total & 1723205628.227 & 12 & & & \\
\hline
\end{tabular}

a. Dependent Variable: Total production

b. Predictors: (Constant), Fertilising, Weeding, Farm Area, Labour

Table 3 indicates that labour and farm area are significant contributors to smallholders' rubber sector, as the p-value is less than the chosen $5 \%$ significance level. The significance level is less than 5\%, although labour has a negative coefficient. The result explains that the smallholders' rubber sector with a larger plantation area generates high production. The weeding coefficient is negative, indicating a negative effect of weeding on smallholders' rubber sector. The p-value for weeding is also more than the $5 \%$ level of significance. Thus, the data do not provide enough evidence to conclude that the weeding process positively affects smallholders' rubber. The regression coefficient is positive $(\beta=0.89)$ for fertilising. 
Nevertheless, the p-value is more than the chosen 5\% significance level, denoting insufficient evidence against the sector.

Table 3: Regression Coefficient

\begin{tabular}{|c|c|c|c|c|c|c|}
\hline \multirow{2}{*}{\multicolumn{2}{|c|}{ Model }} & \multicolumn{2}{|c|}{ Unstandardised Coefficients } & \multirow{2}{*}{$\begin{array}{c}\text { Standardised } \\
\text { Coefficients } \\
\text { Beta } \\
\end{array}$} & \multirow[b]{2}{*}{$\mathrm{T}$} & \multirow[b]{2}{*}{ Sig. } \\
\hline & & B & Std. Error & & & \\
\hline \multirow[t]{5}{*}{1} & (Constant) & -1341.909 & 2542.062 & & -.528 & .612 \\
\hline & Labour & -3.573 & 1.123 & -.792 & -3.181 & .013 \\
\hline & Farm Area & .001 & .000 & 1.579 & 6.985 & .000 \\
\hline & Weeding & -1240.226 & 3011.641 & -.039 & -.412 & .691 \\
\hline & Fertilising & 2052.127 & 2765.438 & .089 & .742 & .479 \\
\hline
\end{tabular}

a. Dependent Variable: Total production

Based on OLS results:

$$
Q=1341.909+0.001 A-3.573 L-1240.226 K+2052 C+\varepsilon
$$

From Table 2 above, the results of multiple regression analysis have shown;

1. $\mathrm{R} 2=0.96$ indicates that $96 \%$ change (variation) in the dependent variable (production yield) is explained by independent variables such as labour, farm area, weeding, and fertiliser.

2. $\mathrm{B} 1=-3.573$ means that a decrease of one labourer will increase production by $3.573 \mathrm{~kg}$, assuming other factors are constant (i.e. significant).

3. $\mathrm{B} 2=0.001$ shows that an increase of one hectare of land will significantly increase the production yield by $0.001 \mathrm{~kg}$.

4. $\mathrm{B} 3=-1240$ indicates a difference in production yield of $1240 \mathrm{~kg}$ between weeding and non-weeding practices.

5. $\mathrm{B} 4=2052$ shows a difference of $2052 \mathrm{~kg}$ in production between fertilising practices according to recommended standards and those that do not follow the standards. Thus, a higher production yield is obtained if the practice of fertilising is undertaken according to the recommended standards.

\section{Discussion}

This study utilised multiple regression analysis to test the relationship between each input type based on the production theory. In addition, the efficiency of production input usage, namely the number of labours, soil productivity, and two agronomic practices, such as fertilising and weeding, are analysed to compare the effects on rubber production throughout Malaysia. The analysis was performed using data from the Rubber Board Survey conducted in 2014 by the MRB. The results showed that $96 \%$ of 
the rubber production yield was explained by independent variables consisting of labour, farm area, weeding and fertilising activities.

The regression results also found that an increase of one hectare of land will lead to an increase in $0.001 \mathrm{~kg}$ production yield, while there is a $1240 \mathrm{~kg}$ difference in production yield between weeding and non-weeding practices. Furthermore, a higher production yield is obtained if fertilising is done according to the recommended standard. In contrast, there is a $2052 \mathrm{~kg}$ production difference between fertilising according to recommended standards and those that do not follow the standard. Overall, the findings found that the total plantation area and agronomic practices affect the production yields but not from labour input. The authors suggest that skills and quality among rubber smallholders must positively impact rubber production in Malaysia.

\section{Conclusions and Recommendations}

Based on the results, there are several recommendations to increase rubber production in Malaysia. The smallholder rubber sector should overcome labour problems and adopt the latest tapping technology to increase production. Besides, the implementation of good agricultural practices needs to be enhanced. The latest tapping technology can reduce labour usage, while more environmentally friendly agricultural practices for tappers can increase the productivity and quality of latex. Advance efforts are required through the implementation agencies to transfer the technology directly to the smallholders through research and development (R\&D) activities, special projects, promotional activities, and advisory and consultancy services.

Mini estates should be established from the combination of smallholders as an efficient measure to increase the productivity of smallholders. Subsequently, the government agencies in charge can monitor rubber tree development to remain highquality, ensure rubber seeds are disease resistant, produce high latex, farmers practice good agronomy and more efficient and effective technology transfer. Examples of this effort are evident from case studies in Malaysia that focused on the viability of remote sensing (Hair \& Muda, 2020), preservation (Teoh, Don, \& Ujang, 2011), and plantation model (Cramb \& Sujang, 2012).

Educational opportunities should be created for smallholder families as education is one of the critical elements in improving the socio-economic status of the smallholders and being at par with other developed countries. The efforts made by RISDA is the best example as RISDA College has produced highly educated smallholders' children. The strengthening of the economic base can ensure the rubber industry's survival and be more successful and sustainable internationally. Furthermore, another essential element is the improvement in technological advancement through R\&D activities should be intensified by the agencies involved, such as the MRB, FELDA, FELCRA, LIGS and the Department of Agriculture. Advancement of technology will resolve the problems in the upstream and downstream levels of the rubber industry, increase the rubber's production and upsurge the income for Malaysia. 
Ramli et al. 


\section{Limitations of the Study}

The study is limited to the rubber smallholders' in Malaysia for the year 2021. Thus, this renders the result of the study applicable solely to these establishments.

\section{Suggestions for Future Research}

Based on the study's limitations, future studies should expand the variables of this study to ensure the policymakers highlight the main factors influencing the production of rubber smallholders' sectors.

\section{Disclosure Statement}

The authors reported no potential conflict of interest.

\section{Funding}

No funding was involved in this research.

\section{Acknowledgement}

We thank Norlee Ramli from the Malaysian Rubber Board for the assistance in giving information on the rubber plantation and production in Malaysia, Oswatun Samat for her assistance with the smallholder sector, Mohd Khairi Ismail for his assistance with methodology technique and Nor Shuhada Ahmad Shaupi with her assistance obtaining literature review. The author's responsibilities were designing the research, writing and editing the manuscript, and had primary responsibility for deciding the final content of the manuscript. All the authors read and approved the final manuscript. None of the authors had a conflict of interest.

\section{References}

Abdulla, I., \& Arshad, F. M. (2017). Exploring relationships between rubber productivity and R\&D in Malaysia. Outlook on Agriculture, 46(1), 28-35.

Ali, M. F., Akber, M. A., Smith, C., \& Aziz, A. A. (2021). The dynamics of rubber production in Malaysia: Potential impacts, challenges and proposed interventions. Forest Policy and Economics, 127, 102449.

Cramb, R. A., \& Sujang, P. S. (2012). Pathways through the plantation: oil palm smallholders and livelihood strategies in Sarawak, Malaysia (No. 423-2016-26996).

Hamermesh, D. S. 1986. The demand for labor in the long run. Handbook of Labor Economics, doi:10.1016/S1573-4463(86)01011-8

Ismail, A. Y. (1984). Pemilihan Klon Mengikut Enviromaks. Getah Asli, 2, 11-13.

Jabatan Perangkaan Malaysia. (2010). Perangkaan Getah Tahunan. ISSN 1823-0938.

Hazir, M. H. M., \& Muda, T. M. T. (2020). The viability of remote sensing for extracting rubber smallholding information: A case study in Malaysia. The Egyptian Journal of Remote Sensing and Space Science, 23(1), 35-47.

LGM. (2010). Pembajaan Tanaman Getah Dewasa. Lembaga Getah Malaysia.

Mohd. Fauzi, M. Y. (2014). Pembajaan Pokok Getah. Sains \& Teknologi, Lembaga Getah Malaysia.

Othman, J. \& Jafari, Y. 2014. Selected issues in the Malaysian agricultural sector. Jurnal Ekonomi Malaysia, 48(2), 127-136.

Perangkaan Getah Tahunan Malaysia 2010. 2010. Jabatan Perangkaan Malaysia. 
Perangkaan Tanaman Getah Malaysia. 2014. Jabatan Perangkaan Malaysia. doi:10.1017/CBO9781107415324.004

Rabiah, M. Y., Mohd. Fairuz Fazli, M. I. \& Kamarozaman, I. (2015). Kajian Perbandingan Keluaran Hasil (GTT) Klon RRIM 2014, RRIM 2015, RRIM 2024 DAN RRIM 2025 di Ladang Hutan Getah, Rriminis Lakai, Negeri Sembilan. Sains \& Teknologi, Lembaga Getah Malaysia.

Rafain Ahuar, Z. D. \& M. N. M. (2012). Membina Senario Masa Hadapan Industri Getah Malaysia : Road Map dan Pemacu Utama Industri Building of the Future Scenario of Malaysian Rubber Industry : Identifying the Road. Prosiding Perkem Vii, Jilid 1, 1, $27-$ 43.

Rahman, S. (2020). Malaysian Independent Oil Palm Smallholders and their Struggle to Survive 2020.

Ramli, O. (2012). Ke arah pengeluaran hasil tinggi melalui amalan pertanian baik. Lembaga Getah Malaysia.

Rosine, J. \& Helmberger, P. (1974). A Neoclassical Analysis of the U. S. Farm Sector, 19481970. American Journal of Agricultural ..., 56(4), 717-729. doi:10.2307/1239301

Said, M. A. M. (2005). Harvesting the yield targeted. Malaysian Rubber Board, Proceedings.

Salisu, M., Daud, N. \& Ahmad, I. 2013. Influence of fertilizer rates and soil series on growth performance of natural rubber (Hevea brasiliensis) latex timber clones. Australian Journal of Crop Science, 7(13), 1998-2004.

Shima, N. \& Kheong, Y. F. (2008). A Study of Fertilizer Requirement for Rubber Forest. eminar Perladangan Hutan Getah Kebangsaan, Kuala Lumpur, 13-14 Nov. 2008,. Lembaga Getah Malaysia.

Teoh, Y. P., Don, M. M., \& Ujang, S. (2011). Assessment of the properties, utilization, and preservation of rubberwood (Hevea brasiliensis): a case study in Malaysia. Journal of Wood Science, 57(4), 255-266.

Wan Noordin, W. D. (1991). Khasiat membaja. Lembaga Getah Malaysia, 12-17.

Zahidin, R. M., Noordin, W. D. W. A. N. \& Zulkefly, S. 2017. The effect of soil series and fertilizer rates on the growth of RRIM 3001. Journal of Rubber Research, 20(1), 43-57.

Zainuddin, R. Transformasi Komuniti Orang Asli Melalui Amalan Pertanian yang Baik (GAP) Tanaman Getah di Negeri Melaka., Sains \& Teknologi 47-51 (2014). Lembaga Getah Malaysia.

Zulkefly, S., Khairul Ashraf, A., Shima, N., Akbar, M., A, G. S. . \& Ikhsan Mashuri. (2010). Ke Arah Pengeluaran Hasil Tinggi Melalui Amalan Pertanian Baik dan Teknologi Penuaian Latek. Seminar Pemindahan Teknologi Kebangsaan, Akademi Hevea Valaysia, Stesen Penyelidikan RRIM Sungai Buloh, 12 October 2010.,. 